\title{
Understorey vegetation gradient in a Eucalyptus grandis plantation between a savanna and a semideciduous forest
}

\author{
Pavel Dodonov ${ }^{1 *}$, Danilo Muniz da Silva ${ }^{2}$ and Natália Bianca Rosatti ${ }^{3}$
}

\begin{abstract}
Background: Plant community assemblage is influenced by many factors, including soil characteristics and the arrival of diaspores from surrounding areas. These factors may be especially important in transition areas, leading to spatial gradients in the plant community.

Methods: This study was performed in the understorey of an abandoned Eucalyptus grandis W. Hill ex Maiden plantation between a savanna and a forest, $490 \mathrm{~m}$ apart, in south-eastern Brazil. This study assessed whether the spatial variation in several variables related to the understorey's structure and composition is best described by linear or non-linear (quadratic) models. The linear model would indicate a gradient between the two vegetation types, whereas the quadratic model would indicate a stronger effect of the plantation's edges.

Results: There was a gradient in species composition between the two edges of the plantation. Mean vegetation height was greatest at the savanna edge and lowest in the centre of the plantation. The total number of individuals per plot and the phylogenetic diversity decreased with distance from the savanna edge. Different patterns were observed for different dispersal syndromes, with animal dispersal being more common at the savanna edge, wind dispersal in the centre of the plantation and self dispersal at the forest edge.

Conclusions: The greater number of individuals at the savanna edge may indicate that dispersal and arrival of diaspores are the most important factors influencing community structure and composition of the understorey of this abandoned $E$. grandis plantation, with most propagules coming from the savanna area. The smaller vegetation height in the centre of the fragment may also indicate older colonisation at the edges. Therefore, in addition to highlighting the recovery potential of undergrowth beneath abandoned Eucalyptus spp. plantations, these results show that this recovery is spatially heterogeneous and that dispersal plays a large role in it. This should be taken into account in restoration projects. The authors recommend careful consideration before removing regenerating Eucalyptus spp. trees as part of the site restoration. Instead the focus should be on the recovery potential of the undergrowth, with gradual removal of Eucalyptus trees, if necessary.
\end{abstract}

Keywords: Cerrado; Community composition; Dispersal; Diversity; Ecotone; Restoration; Structure

\footnotetext{
* Correspondence: pdodonov@gmail.com

'Department of Hidrobiology, Federal University of São Carlos, P.O. Box 676,

São Carlos 13565-905, SP, Brazil

Full list of author information is available at the end of the article
} 


\section{Background}

Reconstructing a natural community is one of the greatest challenges for restoration ecology, partly because community assemblage is determined by several distinct factors such as environmental filters, diaspore availability, competition between and within species, and species potential for colonisation (Webb et al. 2002; Chase 2003). Natural recolonisation may aid in community reconstruction by allowing communities to regenerate with species from neighbouring vegetation patches. However, a successful application of this process requires a better understanding of how species colonise or recolonise disturbed areas (Török et al. 2011). Colonisation is limited mostly by three factors: 1) diaspore availability in the neighbouring species pool and the dispersal capacity of different species (Török et al. 2011); 2) ecological traits that determine the survival and establishment of different species under different environmental conditions (Lebrija-Trejos et al. 2010); and 3) biotic interactions, such as facilitation and competition, that determine the patterns of species co-occurrence (Cianciaruso et al. 2009). This is also true for natural recolonisation of disturbed environments, in which resprouting from pre-existent underground structures may also play an important role (Durigan et al. 1998). Therefore, knowledge of how these factors affect transition area is essential for successful restoration planning.

Transition areas between different vegetation types, for example between savanna and forest, are usually characterised by a gradual shift in environmental conditions and species composition (Furley et al. 1992). In some areas, however, abrupt changes in soil and other environmental characteristics may result in a sharp edge between the different vegetation types (Ruggiero et al. 2002, Durigan and Ratter 2006). In either case, both savanna and forest patches influence the transition area, and the influence is stronger closer to each patch (Cadenasso et al. 2003). This is likely to result in a spatial gradient in species composition during the recolonisation of a transition area, as the occurrence and density of different species will vary with the distance from the source of diaspores (Wolters et al. 2005). The environmental conditions found in the transition area also affect the resulting species composition, as species originating from different environments are adapted to different environmental constraints. For example, savanna species are adapted to decreased soil fertility and water availability (Ruggiero et al. 2002) and to regular fires (Moreira 2000; Miranda et al. 2002), factors that may lead to the local extinction of forest species.

Ecotones between forest and savanna are common in the São Paulo state, south-eastern Brazil, where cerrado sensu stricto, a savanna formation that is part of the larger floristic domain known as the Cerrado, occurs alongside semideciduous forests (Ruggiero et al. 2002; Durigan and
Ratter 2006). Transition areas in this region are often replaced by agricultural and silvicultural land uses. Silviculture, a large part of which uses exotic Eucalyptus spp. trees, is the fifth most frequent land use adjacent to cerrado fragments in the São Paulo state (Durigan et al. 2007). One characteristic of these Eucalyptus spp. plantations is that they often contain an understorey composed of native species (Saporetti Jr et al. 2003; Neri et al. 2005). This understorey may be used as a resource and refuge by animal species and also function as stepping stones or corridors linking natural areas that would not be connected otherwise (Machado and Lamas 1996; Lyra-Jorge et al. 2008). In addition, the understorey can increase local biodiversity by offering regeneration sites for plant species from different vegetation types (Saporetti-Jr et al. 2003).

This understorey may also be used as a starting point to restore native vegetation when the plantation is no longer used, which makes assessments of its composition important for restoration ecology. Other studies (e.g. Durigan et al. 1998, Jepson 2005, Neri et al. 2005) have already shown the potential of natural regrowth in abandoned Eucalyptus spp. plantations; however, these studies have not discussed large-scale spatial variation in the regrowth's structure and composition. The objective of this study was to test for linearity or non-linearity of the gradient in vegetation structure, composition and diversity of the understorey of an abandoned Eucalyptus grandis W. Hill ex Maiden plantation located between a cerrado stricto sensu and a semideciduous forest to provide insights for restoration. The following questions were addressed in this study: (1) Are there gradual changes in species composition, richness, diversity and phylogenetic diversity between the two areas? These gradual changes are expected because both proximity to natural areas and edges affects vegetation structure and species occurrence and distribution (Harper et al. 2005, Wolters et al. 2005). (2) Are these patterns linear or non-linear pattern, with a trough or peak in the middle? As colonisation starts from the edges, greater density of individuals and mean vegetation height should be found closer to the edges. (3) Are there more pronounced gradients on wind- and self-dispersed species than on animaldispersed species? If this area is used homogeneously by the local frugivorous fauna, animals could disperse seed evenly through the area. (4) Do abundant species show a gradient in their distribution between the two areas? Differences in ecological processes and species composition between the savanna and forest areas are likely to affect the distribution of the dominant species in the study area. This article reports the actual compositional and structural variability of the woody species in the study area, discusses its probable causes and whether the results matched expected composition. Conclusions have been drawn and recommendations made for the restoration of natural vegetation in similar areas. 


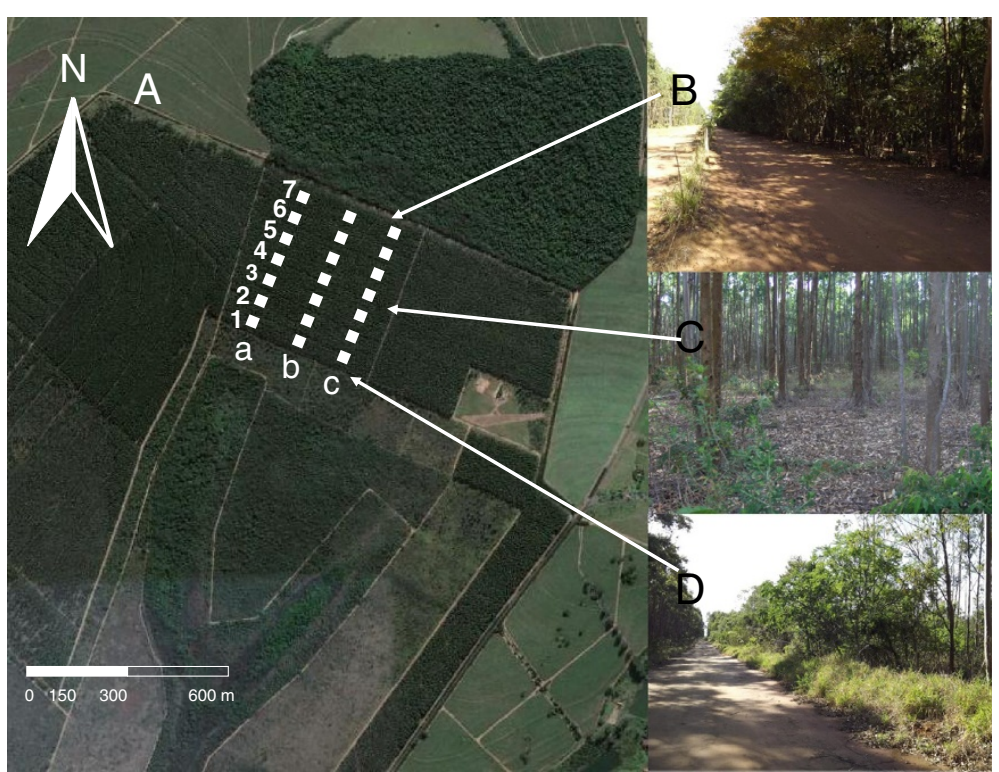

Figure 1 Study areas. A: Satellite image of the study site, located in the north-eastern portion of the Federal University of São Carlos $\left(21^{\circ} 57^{\prime} 50^{\prime \prime} \mathrm{S}, 47^{\circ} 51^{\prime} 55 \mathrm{~W}\right)$ between a semideciduous forest to the north and a savanna to the south (white lines represent the transects); B: the forest edge; $\mathbf{C}$ : the interior of the site; $\mathbf{D}$ : the cerrado edge.

\section{Methods}

\section{Study area and sampling methods}

This study was conducted in the understorey of a site $490 \mathrm{~m}$ wide and $490 \mathrm{~m}$ long in the north-eastern portion of the Federal University of São Carlos $\left(21^{\circ} 57^{\prime} 50^{\prime \prime}\right.$ S, 4751'55" W, 815-890 m a.s.l.; Santos et al. 1999), in São Paulo state, Brazil. This site had been used previously as a Eucalyptus grandis plantation and was last harvested approximately 15 years prior to the study. It had not been managed since then and E. grandis trees had regrown from stumps left after the last harvest. These trees were approximately $15 \mathrm{~m}$ tall at the time of the study, with a highly homogeneous tree cover throughout the study site. This site is located between two natural areas: a semideciduous forest to the north and a regenerating cerrado sensu stricto savanna to the south (Figure 1). The predominant vegetation of the cerrado was fully grown native trees but there were also a few, widely spaced Eucalyptus spp. trees that had regenerated for more than 20 years from an previous Eucalyptus spp. plantation. The regional climate is seasonal, with dry winters and wet summers. Soils are acidic and nutrient-poor Oxisols with high aluminium content (Santos et al. 1999).

Three transects were placed between the cerrado and forest edges, with $150 \mathrm{~m}$ between adjacent transects (Figure 1). Seven $25 \times 25$ m plots were delimited in each transect, leaving $50 \mathrm{~m}$ between consecutive plots. The first and last plot of each transect were placed approximately $10 \mathrm{~m}$ from the cerrado and forest edges, respectively. The three transects were labelled as "a", "b" and "c", and the plots in each transect were numbered from 1 , corresponding to the plot closest to the cerrado edge, to 7 , corresponding to the plot closest to the forest edge. Therefore, plot a1 is the plot of transect "a" that is closest to the cerrado and plot c7 is the plot of transect "c" that is closest to the forest. The three transects were treated as replicates and used the distance between the centre of each plot and the cerrado edge (i.e. $22.5 \mathrm{~m}$ for plot 1 and $472.5 \mathrm{~m}$ for plot 7) as the explanatory variable. Within each plot, all woody non-vine plants with height greater than $50 \mathrm{~cm}$ were sampled, considering stems that were clearly separated at soil level as different individuals, and classified them into four height classes: $<1.4 \mathrm{~m}, 1.4-1.6 \mathrm{~m}, 1.61-3 \mathrm{~m}$, and $>3 \mathrm{~m}$. All individuals to were then identified species level by consulting specialised literature and a taxonomist (see Acknowledgments) and classified all species into dispersal syndromes (wind-, self- and animal-dispersed) based on literature reviews or on the information available for other species of the same genus. As the E. grandis trees had been planting without prior removal of the underground plant structures (pers. comm., Maria Inês S. Lima), native species in this area may have originated either by resprouting or from recruitment. However, it was not possible to differentiate between these two types in the field.

\section{Data analysis}

\section{Ordination analysis of vegetation composition}

General differences in species composition among the sampling plots were assessed by means of a non-metric 
multidimensional scaling (NMDS) analysis, performed on untransformed data with the algorithm developed by Taguchi \& Oono (2005), using Past 2.10 sofrware (Hammer et al. 2001). Two similarity indices were used to assess the presence-absence and abundance patterns: the Jaccard index, which takes into account only the presence of a given species, and the Horn index, which considers the relative abundance of all the species (Jost et al. 2011).

\section{Vegetation variables}

The data were described with 23 response variables related to species diversity, phylogenetic diversity, vegetation structure, dispersal syndrome, and distribution of abundant species. For species diversity, two measures of species richness were used, namely the number of species and the Fisher's alpha diversity index, as well as Shannon's diversity index and the corresponding Pielou's evenness index (Magurran 1988), calculated in Past 2.10. The Fisher's alpha diversity index was used because species richness per se usually increases with increasing number of individuals, whereas the Fisher's alpha diversity index is a robust species richness estimate that is not influenced by biases in the number of individuals (Maurer and McGill 2011). To use Fisher's alpha diversity index, the species abundance distribution should not be different from the log-series (Maurer and McGill 2011), which was the case for our data $(p=1$, as calculated using the Past 2.10 software).
Phylogenetic diversity was assessed by means of two indices, phylogenetic diversity (PD) and phylogenetic diversity-rate (PD-rate). The Phylomatic module of the Phylocom software was used to construct a phylogenetic tree of all the species sampled (Webb and Donoghue 2005; Webb et al. 2008). The lengths of the branches were estimated based on the current Phylomatic tree (tree R20091110; Webb et al. 2008) with APG III (Angiosperm Phylogeny Group 2009) and Wikström ages (Wikström et al. 2001). The root node and all the dated nodes were fixed, and the undated nodes were placed evenly between the dated nodes or between the dated nodes and the terminal nodes by means of the "bladj" algorithm in the Phylocom software (Webb et al. 2008). The calculation of PD was done by summing the lengths of the branches of the phylogenetic tree obtained for each plot (Faith 1992). The units used for PD were millions of years (My). PD-rate was calculated by dividing PD by the number of species in each plot. Whereas PD is a measure of the phylogenetic distance between species in a community, PD-rate permits to verify whether the variation in PD is due to the number of species present or to the phylogenetic differences between the species. A low PD-rate indicates that the PD value at a site is due mostly to the number of species present, whereas a high PD-rate indicates that the PD is a result of the phylogenetic distances between the species.

The total number of individuals, the average vegetation height, the standard deviation of height and the coefficient of variation (calculated by dividing the standard
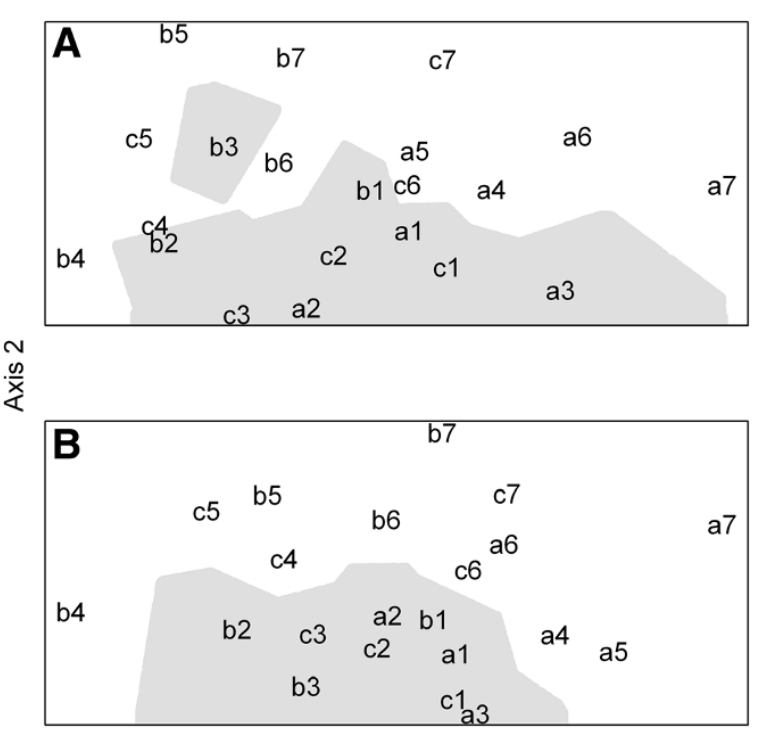

Axis 1

Figure 2 Gradient in the floristic composition in the understorey of the study site. Non-metrical multi-dimensional scaling using: A: Jaccard distance; and $\mathbf{B}$ : Horn distance. Letters $a, b$ and $c$ represent the three transects, and numbers 1 to 7 represent plots at the following distances from the cerrado edge: (1) 10-35 m; (2) 85-110 m; (3)160-185 m; (4) 235-260 m; (5) 310-335 m; (6) 385-410 m; and (7) 460-485 m. Grey areas represent areas of the ordination plot that are closer to plot 1, 2 and 3 than to the other plots, showing a pattern in the analysis performed with Horn distance. Stress: $\mathbf{A}=0.3223, \mathbf{B}=0.2489$. 
Table 1 Floristic composition of the study area

\section{Species}

\section{N}

Rank

Distances

Dispersal

Anacardiaceae

Astronium graveolens Jacq.

21

Tapirira guianensis Aubl.

6

24

36

$1-7$

$1-3,5$

Wind $^{23}$

Annonaceae

Annona coriacea Mart 18

Annona crassiflora Mart.

Duguetia furfuracea (A.St.-Hil.) Saff.

Guatteria nigrescens Mart.

Xylopia aromatica (Lam) Mart.

Xylopia frutescens Aubl.

Aquifoliaceae

llex cerasifolia Reissek

3

Araliaceae

Schefflera vinosa (Cham. \& Schltdl.) Frodin \& Fiaschi

204

Asteraceae

Baccharis dracunculifolia DC

Chromolaena cf. laevigata (Lam.) R.M. King \& H. Rob.

Eupatorium cf. megaphyllum Baker

Gochnatia pulchra Cabrera

Piptocarpha axillaris (Less.) Baker

Piptocarpha macropoda (DC.) Baker

Piptocarpha rotundifolia (Less.) Baker

Piptocarpha sp. Hook. \& Arn.

Vernonanthura cf puberula (Less.) H. Rob.

Vernonanthura phosphorica (Vell.) H. Rob.

Vernonia rubriramea Mart. ex DC.

Bignoniaceae

Handroanthus chrysotrichus(Mart. ex DC.) Mattos.

Handroanthus ochraceus (Cham.) Mattos

Jacaranda caroba (Vell.) DC.

Tecoma stans (L.) Juss. ex Kunth

Zeyheria montana Mart.

Zeyheria tuberculosa (Vell.) Bureau ex Verl.

Burseraceae

Protium heptaphyllum (Aubl.) Marchand

Caryocaraceae

Caryocar brasiliense A.St.-Hil.

10

Celastraceae

Tontelea micrantha (Mart. ex Schult.) A.C. Sm.

Connaraceae

Connarus suberosus Planch.

Rourea induta Planch.

Ebenacae

Diospyros hispida A.DC.
26

1,4

$1-5$

7

$1-5,7$

5,7

5-7

$1-7$

$1-6$

6

7

$1,3,4$

$3,6,7$

1,5-7

1-7

3-5

2

$1-3$

$1-4,6,7$

1,3

$2,3,5$

3-7

1-7

3

6

5

2-5

3
Animal $^{15}$

Animal ${ }^{15}$

Animal $^{15}$

Animal $^{17}$

Animal $^{1}$

Animal ${ }^{34}$

Animal $^{31}$

Animal $^{14}$

Wind $^{9}$

Wind $^{32}$

Wind

Wind $^{28}$

Wind $^{16}$

Wind $^{31}$

Wind $^{15}$

Wind $^{35}$

Wind $^{33}$

Wind $^{14}$

Wind $^{28}$

Wind $^{31}$

Wind $^{15}$

Wind $^{28}$

Wind $^{18}$

Wind $^{28}$

Wind $^{31}$

Animal $^{26}$

Animal $^{15}$

Animal $^{24}$

Animal $^{15}$

Animal $^{15}$

Animal $^{15}$ 
Table 1 Floristic composition of the study area (Continued)

Erythroxylaceae

$$
\begin{aligned}
& \text { Erythroxylum cf. deciduum A.St.-Hil. } \\
& \text { Erythroxylum cuneifolium (Mart.) O.E. Schulz } \\
& \text { Erythroxylum suberosum A.St.-Hil. }
\end{aligned}
$$

Euphorbiaceae

$$
\begin{aligned}
& \text { Alchornea triplinervia (Spreng.) Müll. Arg. } \\
& \text { Sapium glandulosum (L.) Morong }
\end{aligned}
$$

Fabaceae

$$
\text { Acacia recurva Benth. }
$$

Acosmium dasycarpum (Vogel) Yakovlev

Acosmium subelegans (Mohlenbr.) Yakovlev

Anadenanthera peregrina (L.) Speg.

Andira inermis (Wright) DC.

Bauhinia rufa (Bong.) Steud.

Bowdichia virgilioides Kunth

Chamaecrista flexuosa (L.) Greene

Copaifera langsdorffii Desf.

Dalbergia miscolobium Benth.

Dimorphandra mollis Benth.

Machaerium acutifolium Vogel

Machaerium nyctitans (Vell.) Benth.

Machaerium stipitatum (DC.) Vogel

Pterogyne nitens Tul.

Senna rugosa (G. Don) H.S. Irwin \& Barneby

Senna splendida (Vogel) H.S. Irwin \& Barneby

Stryphnodendron adstringens (Mart.) Coville

Stryphnodendron obovatum Benth.

Lamiaceae

Aegiphila Ihotzkiana Cham.

Lauraceae

Endlicheria paniculata (Spreng.) J.F. Macbr.

Ocotea pulchella (Nees \& Mart.) Mez

Malpighiaceae

Byrsonima intermedia A. Juss.

Malvaceae

Eriotheca gracilipes (K. Schum.) A. Robyns

Melastomataceae

Leandra lacunosa Cogn.

Miconia albicans (Sw.) Steud.

Miconia cf. ligustroides(DC.) Naudin

Miconia fallax DC.

Miconia ligustroides (DC.) Naudin

Miconia rubiginosa (Bonpl.) DC.

Miconia stenostachya DC.$$
23
$$

4

17

41

\section{2,4 \\ 2,3,5-7}

$1,2,4$

1.4-7

$1,3,4,7$

Animal $^{31}$

Self ${ }^{31}$

Wind $^{26}$

Wind $^{15}$

Self ${ }^{29}$

Animal $^{25}$

Self ${ }^{15}$

Wind $^{15}$

Self ${ }^{24}$

Animal'

Wind $^{15}$

Animal ${ }^{15}$

Wind ${ }^{1}$

Wind $^{4}$

Wind $^{31}$

Wind $^{27}$

Self ${ }^{28}$

Self ${ }^{34}$

Animal ${ }^{28}$

Self ${ }^{15}$

Animal $^{29}$

Animal $^{33}$

Animal $^{8}$

1-7

Animal $^{15}$

Wind $^{29}$

Animal $^{14}$

$1,3,5$

Animal $^{15}$

1-7

Animal $^{15}$

Animal $^{29}$ 
Table 1 Floristic composition of the study area (Continued)

Meliaceae

Cabralea canjerana (Vell.) Mart.

Cedrela fissilis Vell.

Moraceae

Brosimum gaudichaudii Trécul

Ficus of citrifolia Mill.

Myristicaceae

Virola sebifera Aubl.

Myrtaceae

Calyptranthes concinna DC.

Calyptranthes lucida Mart. ex DC.

Campomanesia adamantium (Cambess.) O. Berg

Campomanesia pubescens (Mart. ex DC.) O. Berg

Campomanesia sp. Ruiz \& Pav.

Eugenia of klotzschiana O. Berg

Eugenia dysenterica DC.

Eugenia obversa O. Berg

Eugenia punicifolia (Kunth) DC.

Eugenia pyriformis Cambess.

Myrcia bella Cambess.

Myrcia cf. tomentosa (Aubl.) DC.

Myrcia fallax DC.

Myrcia lingua (O. Berg) Mattos \& D. Legrand

Myrcia tomentosa (Aubl.) DC.

Psidium grandifolium Mart. ex DC.

Psidium guajava L.

Psidium laruotteanum Cambess.

Nyctagenaceae

Guapira noxia (Netto) Lundell

Guapira opposita (Vell.) Reitz

Ochnaceae

Ouratea spectabilis (Mart. ex Engl.) Engl.

Peraceae

Pera glabrata (Schott) Poepp. ex Baill.

Phyllantaceae

Phyllanthus acuminatus Vahl

Seguieria cf. americana L.

Primulaceae

Myrsine coriacea (Sw.) R.Br. ex Roem. \& Schult.

Myrsine umbellata Mart.

Proteaceae

Roupala montana Aubl.

Rubiaceae

Chomelia cf. obtusa Cham. \& Schltdl.

Cordiera concolor (Cham.) Kuntze
Wind $^{9}$

Animal $^{29}$

Animal $^{13}$

Animal $^{13}$

Animal $^{15}$

Animal $^{15}$

Animal $^{13}$

Animal $^{13}$

Animal $^{1}$

Animal ${ }^{13}$

Animal $^{15}$

Animal $^{13}$

Animal ${ }^{15}$

Animal $^{13}$

Animal $^{15}$

Animal $^{13}$

Animal ${ }^{13}$

Animal $^{24}$

Animal $^{13}$

Animal $^{24}$

Animal ${ }^{15}$

Animal $^{10}$

Animal $^{15}$

Animal $^{15}$

Self ${ }^{22}$

Wind $^{6}$

Self ${ }^{15}$ 
Table 1 Floristic composition of the study area (Continued)

\begin{tabular}{|c|c|c|c|c|}
\hline Cordiera sessilis (Vell.) Kuntze & 1 & 41 & 2 & Animal $^{28}$ \\
\hline Palicourea rigida Kunth & 3 & 39 & 2,5 & Animal $^{15}$ \\
\hline Psychotria nuda (Cham. \& Schltdl.) Wawra & 5 & 37 & $1,2,6,7$ & Animal $^{3}$ \\
\hline Rudgea viburnoides (Cham.) Benth. & 11 & 32 & $1,3,5-7$ & Animal $^{29}$ \\
\hline Tocoyena formosa (Cham. \& Schltdl.) K. Schum. & 2 & 40 & 1 & Animal $^{15}$ \\
\hline \multicolumn{5}{|l|}{ Rutaceae } \\
\hline Zanthoxylum cf. fagara (L.) Sarg. & 2 & 40 & 2 & Animal $^{5}$ \\
\hline Zanthoxylum rhoifolium Lam. & 10 & 33 & $1-3,6$ & Animal $^{10}$ \\
\hline \multicolumn{5}{|l|}{ Salicaceae } \\
\hline Casearia silvestris Sw. & 12 & 31 & $2-6$ & Animal $^{15}$ \\
\hline \multicolumn{5}{|l|}{ Siparunaceae } \\
\hline Siparuna guianensis Aubl. & 29 & 19 & $1-4,6,7$ & Animal $^{4}$ \\
\hline \multicolumn{5}{|l|}{ Solanaceae } \\
\hline Solanum lycocarpum A. St.-Hil. & 48 & 14 & $1,2,4,7$ & Animal $^{2}$ \\
\hline Solanum mauritianum Scop. & 58 & 10 & $1-7$ & Animal $^{7}$ \\
\hline Solanum paniculatum L. & 95 & 5 & $1,2,4-7$ & Animal $^{14}$ \\
\hline Solanum pseudoquina A. St.-Hil. & 1 & 41 & 5 & Animal $^{30}$ \\
\hline Solanum reflexum Schrank & 1 & 41 & 2 & Animal $^{35}$ \\
\hline Solanum viarum Dunal & 14 & 29 & $2,4,6,7$ & Animal $^{19}$ \\
\hline \multicolumn{5}{|l|}{ Styracaceae } \\
\hline Styrax ferrugineus Nees \& Mart. & 10 & 33 & $1,2,4,5$ & Animal $^{15}$ \\
\hline \multicolumn{5}{|l|}{ Thymelaeaceae } \\
\hline Daphnopsis fasciculata (Meisn.) Nevling & 6 & 36 & $1,3,4,6,7$ & Animal $^{21}$ \\
\hline \multicolumn{5}{|l|}{ Urticaceae } \\
\hline Cecropia pachystachya Trécul & 1 & 41 & 5 & Animal $^{23}$ \\
\hline \multicolumn{5}{|l|}{ Vochysiaceae } \\
\hline Qualea cf. multiflora Mart. & 1 & 41 & 3 & Wind $^{15}$ \\
\hline Vochysia tucanorum Mart. & 5 & 37 & 1,2 & Wind $^{31}$ \\
\hline
\end{tabular}

Species are shown with the corresponding total number of sampled individuals (N), abundance rank (from the most to the least abundant), the plots at which the species was found (from 1 - closest to the cerrado edge to 7 - closest to the forest edge), dispersal syndrome (wind-, self- or animal-dispersed), and reference for the dispersal syndrome as superscripts. Families, authors, synonyms and accepted names were checked on The Plant List (2010) or Tropicos (Missouri Botanical Garden 2012) databases with the Plantminer software (Carvalho et al. 2010).

${ }^{1}$ Almeida et al. 1998; ${ }^{2}$ Batalha and Mantovani 2000; ${ }^{3}$ Borgo $2010 ;{ }^{4}$ Campos et al. 2009; ${ }^{5}$ Candiani $2006 ;{ }^{6}$ Catharino et al. 2006; ${ }^{7}$ Coelho et al. 2010; ${ }^{8}$ Francisco and Galetti 2002; ${ }^{9}$ Frenedoso 2004; ${ }^{10}$ Galetti et al. 2011; ${ }^{11}$ Giehl et al. 2007; ${ }^{12}$ Goldenberg and Shepherd $1998 ;{ }^{13}$ Gressler et al. 2006; ${ }^{14}$ Ishara and MaimoniRodella 2011; ${ }^{15}$ Jardim and Batalha 2009; ${ }^{16}$ Liebsch et al. 2009; ${ }^{17}$ Lobão and Mello-Silva 2007; ${ }^{18}$ Grau et al. $1997 ;{ }^{19}$ Paise and Vieira $2005 ;{ }^{20}$ Pascotto $2007 ;{ }^{21}$ Polisel and Franco 2010; ${ }^{22}$ Ressel et al. 2004; ${ }^{23}$ Reys et al. 2005; ${ }^{24}$ Silva et al. 2009; ${ }^{25}$ Spina et al. 2001; ${ }^{26}$ Stefanello et al. $2009 ;{ }^{27}$ Takahasi and Fina 2004; ${ }^{28}$ Tannus et al. 2006; ${ }^{29}$ Weiser and Godoy 2001; ${ }^{30}$ Wiesbauer et al. 2008; ${ }^{31}$ Yamamoto et al. 2007; ${ }^{31}$ Yamamoto et al. 2007 (for Myrsine umbellata); ${ }^{32}$ Ye et al. 2004 (for Cedrela odorata); ${ }^{33}$ Zipparro et al. 2005; ${ }^{34}$ Moura et al. $2011 ;{ }^{35}$ based on species from the same genus.

deviation by the mean height) were used to characterise the vegetation structure. To calculate average vegetation height, we considered that the height of each individual corresponds to the mid-value of its height class $(4.5 \mathrm{~m}$ for the last class, as most tall trees were still under $6 \mathrm{~m}$ in height) and calculated the mean of these mid-values. We used the same mid-values to estimate standard deviation, which was used as a measure of structural variability within the plot. The number and proportion of wind-, self-, and animal-dispersed individuals and species within each plot were used to analyse the dispersal syndromes. We also analysed the distribution of the seven species with at least 90 individuals because patterns of abundant species may indicate important ecological processes.

\section{Regressions}

Both quadratic and linear regressions were examined to assess the existence and shape of the gradient with respect to the 23 response variables, in the software R 2.13 ( $\mathrm{R}$ Core Development Team, 2012). Distance from the cerrado edge was specified as the explanatory variable. We chose quadratic regressions because they fit with the expected pattern of more extreme values at both edges, 
with either a trough or a peak at intermediate distances. In contrast, a linear regression would show a linear increase in the response variable along each transect. We considered a quadratic regression significant only when its quadratic term $\left(x^{2}\right)$ was also significant; otherwise we considered the linear regression to be a better model. We considered a significance level of 0.05 for all tests.

\section{Results}

\section{Vegetation composition}

Non-metrical multidimensional scaling ordination was conducted using both the Jaccard and Horn distance indices, Figure 2A \& B, respectively. No clear separation among sites was generated with the Jaccard distance index but was more obvious when the Horn distance index was used. Specifically, the three plots of each transect that were closer to the cerrado edge were placed more closely together on the ordination plot with the Horn distance index. This resulted in a trend in species composition that may be represented by two zones, up to $185 \mathrm{~m}$ (plot 3 ) from the cerrado edge and further (Figure 2B). These results indicate that, even though there is a change in species abundances along the gradient, complete species replacement does not occur. Furthermore, in the ordination diagrams, plots located along the same transect appear to be more similar to one another than plots of different transects, although this separation is not as clear as for edge distances (Figure 2).

\section{Vegetation variables}

There were 2235 individuals, which corresponded to 1702 individuals per hectare. These individuals belonged to 123 species from 81 genera and 39 families (Table 1).

Number of species and Fisher's alpha diversity index varied from 24 to 44 among the plots. Shannon's diversity index varied between 2.8 and 3.4 natural logarithm digits (nats) per individual. Pielou's evenness index varied between 0.46 and 0.88. The PD varied between 1958 and 2995, PD-rate varied between 68 and 82, and the number of individuals per plot varied from 40 to 199 . Most of the plants encountered were small $(75.7 \%$ of individuals in the first height class, $9.6 \%$ in the second, $11.9 \%$ in the third and $2.8 \%$ in the fourth). The most abundant dispersal syndrome was animal dispersal, with 1776 individuals and 83 species, followed by wind dispersal, with 253 individuals and 31 species, and self dispersal, with 206 individuals and 9 species (Table 1).

The most abundant species were Schefflera vinosa (Cham. \& Schltdl.) Frodin \& Fiaschi (Araliaceae, N = 204), Ocotea pulchella (Nees \& Mart.) Mez (Lauraceae, $\mathrm{N}=171$ ), Phyllanthus acuminatus Vahl (Phyllanthaceae, $\mathrm{N}=123$ ), Myrcia lingua (O. Berg.) Mattos \& D. Legrand (Myrtaceae, $\mathrm{N}=100$ ), Solanum paniculatum L. (Solanaceae, $\mathrm{N}=95$ ), Myrsine umbellata Mart and Myrsine coriacea (Sw.) R.Br. ex Roem. \& Schult. (Primulaceae, $\mathrm{N}=93$ and 90 respectively). The most abundant families were Myrtaceae, Solanaceae, Araliaceae, Fabaceae, and Primulaceae, with 336, 217, 204, 185 and 183 individuals respectively, and the most species-rich families were Fabaceae, Myrtaceae, Asteraceae, Melastomataceae, and Rubiaceae, with 19, 18, 11, 7 and 7 species respectively (Table 1).

\section{Analysis of vegetation variables using quadratic and linear regressions}

A single outlier, located at $322.5 \mathrm{~m}$ from the cerrado edge was removed from the analysis of variables related to vegetation height because this plot was partially occupied by the invasive fern Pteridium esculentum arachnoideum. The presence of this fern may have affected the size structure of the plot by reducing the number of plants in the smaller size classes. Ten out of the 23

Table 2 Coefficient of determination $\left(\mathbf{R}^{2}\right)$ of linear and quadratic regressions between the response variables and distance from cerrado edge along the transects

\begin{tabular}{lll}
\hline Response variable & Linear $\mathbf{R}^{2}$ & Quadratic $\mathbf{R}^{2}$ \\
\hline Number of species & $0.36^{* *}$ & 0.38 \\
Fisher's alpha diversity index & $<0.01$ & $0.28^{*}$ \\
Shannon H index & 0.01 & $0.35^{* *}$ \\
Pielou Evenness index & $0.20^{*}$ & $0.41^{*}$ \\
PD & $0.23^{*}$ & 0.25 \\
PD rate & $0.41^{* *}$ & 0.43 \\
Number of individuals & $0.37^{* *}$ & $0.55^{*}$ \\
Mean height & 0.03 & $0.41^{* *}$ \\
SD of height & 0.18 & $0.42^{*}$ \\
CV of height & $0.23^{*}$ & 0.35 \\
Wind-dispersed individuals & 0.01 & $0.28^{*}$ \\
Self-dispersed individuals & $0.21^{*}$ & 0.22 \\
Animal-dispersed individuals & $0.21^{*}$ & 0.35 \\
Wind-dispersed species & $<0.01$ & $<0.01$ \\
Self-dispersed species & $<0.01$ & 0.02 \\
Animal-dispersed species & $<0.01$ & 0.01 \\
Abundance of Schefflera vinosa & $0.68^{* * *}$ & $0.78^{*}$ \\
Abundance of Ocotea pulchella & $0.19^{*}$ & 0.27 \\
Abundance of Phyllanthus acuminatus & 0.04 & $0.33^{*}$ \\
Abundance of Myrcia lingua & 0.17 & 0.17 \\
Abundance of Solanum paniculatum & 0.09 & 0.09 \\
Abundance of Myrsine coriacea & $0.19^{*}$ & $0.43^{*}$ \\
Abundance of Myrsine umbellata & $0.33^{* *}$ & $0.48^{*}$ \\
\hline & For the vaiabs & \\
\hline
\end{tabular}

For the variables related to vegetation height, we removed a single outlier, located at $322.5 \mathrm{~m}$ from the cerrado edge. We chose to remove this outlier because this plot was partially occupied by the invasive fern Pteridium esculentum arachnoideum, which may have affected the size structure of the plot by reducing the number of plants in the smaller size classes. ${ }^{*} \mathrm{p}<0.05$; ${ }^{* *} \mathrm{p}<0.01$; *** $\mathrm{p}<0.001$. 


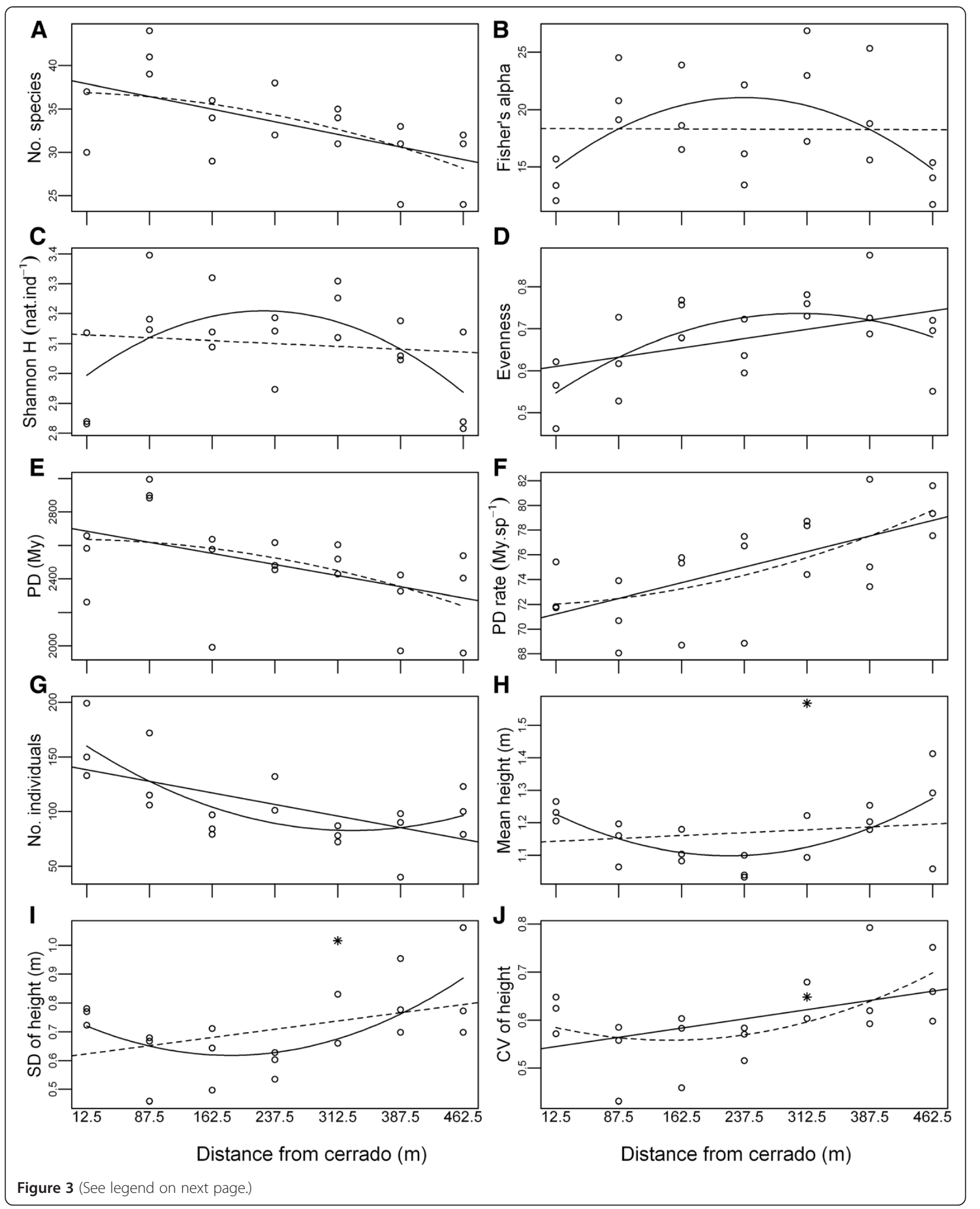


(See figure on previous page.)

Figure 3 Quadratic and linear regressions between the diversity or structural response variables and distance from cerrado edge, represented as the mid-point of each plot, along three transects in the understorey of the study site. Each plot presents two lines, one for quadratic regression, and other for linear regression. Significant regressions are presented with a continuous line, non-significant ones with an interrupted line. Please note that some of variables presented significance for both quadratic and linear regression. A: number of species (i.e. species richness), B: Fisher's alpha diversity index, C: Shannon's H index, D: Pielou's evenness index, E: Phylogenetic diversity (PD), F: Phylogenetic diversity rate, G: total number of individuals, $\mathbf{H}$ : mean vegetation height, I: vegetation height standard deviation, $\mathbf{J}$ : vegetation height coefficient of variation. For the variables related to vegetation height, we removed a single outlier, located at $322.5 \mathrm{~m}$ from the cerrado edge and indicated by a*

response variables tested exhibited significant quadratic relationships with edge distance, with $\mathrm{R}^{2}$ ranging from 0.29 to 0.55 (Table 2), except for the distribution of Schefflera vinosa, which had an $\mathrm{R}^{2}$ of 0.78 . Shannon's $\mathrm{H}$ index, Fisher's alpha diversity index, and the proportion of wind-dispersed individuals had peak values in the middle of the study site, whereas total number of individuals, mean height, height $\mathrm{SD}$, and the distributions of S. vinosa, Myrsine umbellata and Myrsine coriacea all had a trough in the middle plots (Figures 3 and 4). Shannon's evenness, PD-rate, height $\mathrm{CV}$, and proportion of self-dispersed individuals increased from the cerrado to the forest edge, and species richness, PD, number of individuals, number of animal-dispersed individuals, and the distributions of S. vinosa, M. umbellata and M. coriacea, Phyllantus acuminatus and Ocotea pulchella all decreased from the cerrado to the forest edge (Figures 3 and 4). The $\mathrm{R}^{2}$ of the linear regressions ranged from 0.19 to 0.36 . Only five variables, namely the proportion of wind-dispersed, self-dispersed and animal-dispersed species and the abundances of Myrcia lingua and Solanum paniculatum, did not present any significant distance-driven relationships (Figure 4).

\section{Discussion}

The primary result of this study was the large number of species (126) found in the understorey of the study site. Other surveys of understorey in cerrado areas containing Eucalyptus spp. trees have found much lower numbers (between 39 and 47 species) (Saporetti Jr et al. 2003, Neri et al. 2005). This variation may be at least partially due to differences in methodology as these earlier studies only included individuals with at least $3 \mathrm{~cm}$ diameter at soil level. The density of individuals of native species (1700 ind.ha ${ }^{-1}$ ) in the current study was between two and five times smaller than observed in two nearby cerrado areas, where density ranged between 4000 and 8250 ind.ha ${ }^{-1}$ (Dantas and Batalha 2011, Gonçalves and Batalha 2011). This difference in density is even more pronounced given that the sampling criterion used in the current study included individuals with less than $3 \mathrm{~cm}$ diameter. Even so, the density observed in our study is within the recommended density of pre-existent or planted trees for the restoration of cerrado areas, which ranges from 1000 up to 2000 ind.ha $^{-1}$ (Durigan et al.
2003), showing that land used previously as Eucalyptus plantations may have a large potential for natural regeneration and restoration. The potential for regeneration of cerrado vegetation has already been documented for areas previously used as pasture or as Eucalyptus plantation (Durigan et al. 1998, Jepson 2005, Neri et al. 2005). For example, in one study in eastern Mato Grosso state, central Brazil, over $50 \%$ of once-cleared cerrado areas experienced regeneration during the 13-year study period, mostly without human intervention (passive restoration) (Jepson 2005). In addition to the results of these studies, our study showed that the regenerating vegetation is a phylogenetically diverse community, showing that not only many species occurred but that these species belonged to phylogenetically distant groups.

The undergrowth vegetation was spatially heterogeneous, with a conspicuous gradient in the undergrowth between the cerrado and the semideciduous forest. Of the above-mentioned studies, only one (Neri et al. 2005) explored the spatial variation in the regenerating vegetation, but on a much smaller scale than our study. As expected, the proximity to native vegetation of either cerrado or semideciduous forest influenced species composition in the transition area. It appears that the species composition of plots between 0 and $185 \mathrm{~m}$ from the cerrado edge was more similar to that of the cerrado than plots further away (Figure 2). Changes in relative abundances were more evident than changes in species composition, as indicated by the lack of an obvious pattern in the NMDS ordination plot based on the Jaccard Index, which is a presence-absence similarity index. The most abundant species, i.e. those that were better able to recolonise this altered area, were from distinct families at the cerrado and forest edges. Species in the family Meliaceae were more abundant at the forest edge and members of the Araliaceae more abundant at the cerrado edge. The distribution of some of the most abundant species, S. vinosa and O. pulchella, decreased from the cerrado to the forest edge. In fact, of the most abundant species, only $M$. lingua and S. paniculatum did not present a distance-related trend. The importance of the semideciduous forest in determining the composition of this area is emphasised by the presence of typical forest species (e.g. Cedrela fissilis and Cabralea canjerana) closer to the forest edge. Thus, even though most 


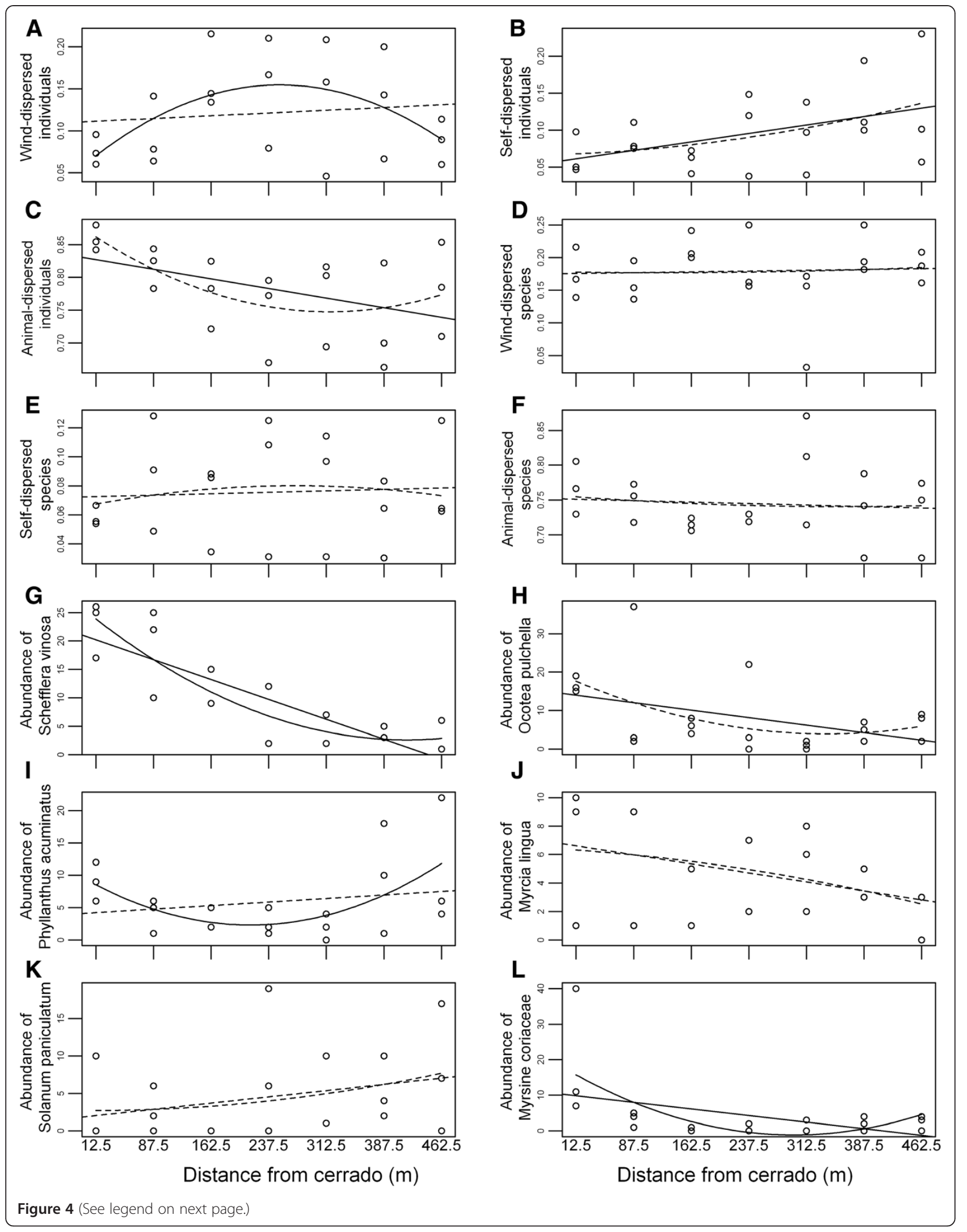


(See figure on previous page.)

Figure 4 Quadratic and linear regressions between the dispersal mode and species abundance response variables and distance from the cerrado edge, represented as the mid-point of each plot, along three transects in the understorey of the study site. Each graph presents two lines, one for quadratic regression, and other for linear regression. Significant regressions are presented with a continuous line, non-significant ones with an interrupted line. Please note that some of variables presented significance for both quadratic and linear regression. A: proportion of wind-dispersed individuals, B: proportion of self-dispersed individuals, C: proportion of animal-dispersed individuals, D: proportion of wind-dispersed species, E: proportion of self-dispersed species, F: proportion of animal-dispersed species, G: distribution of Schefflera vinosa, H: distribution of Ocotea pulchella, I: distribution of Phyllanthus acuminatus, J: distribution of Myrcia lingua, K: distribution of Solanum paniculatum, L: distribution of Myrsine coriacea. The pattern observed for Myrsine umbellata was similar to that of Myrsine coriacea and is not shown.

species occur throughout the entire area, the composition of the whole community follows the cerrado-forest gradient, probably as a result of a variety of dispersal and establishment characteristics (Wulf and Heiken 2008, Pouliot et al. 2012) of cerrado and forest species. In disturbed areas, plasticity and order of establishment usually have more pronounced effects on species' abundances than biotic interactions (Pouliot et al. 2012). Competition among native species is expected to be low at the current study site due to the low density of native trees. Therefore, the spatial structure encountered suggests that dispersal and recruitment are the main determinants of the species composition in this and other altered areas.

Measures of species diversity, phylogenetic diversity, vegetation structure, dispersal syndromes and distribution of abundant species also formed spatial gradients. Notwithstanding the small sample size and large variability between plots, many quadratic regressions were significant, suggesting that the forest and cerrado areas do in fact influence the gradients in composition, structure and distributions of this understorey community. The observed gradients are not likely to be explained by resprouting, which is common for, e.g., S. vinosa and species of the genus Miconia (pers. obs.), among many others (Hoffmann and Solbrig 2003), because resprouting would be expected to be more homogeneous throughout the study site. As large changes in soil properties are not expected at this spatial scale (Dantas and Batalha 2011), the observed gradient in species diversity and other characteristics probably resulted from the distance to the source of diaspores, similarly to what we observed for species composition.

Phylogenetic diversity decreased from cerrado to the forest edge, mainly due to decreasing richness towards the forest edge. As speciation is not important at the time scale addressed here, the colonisation process alone turns out as the major factor in determining patterns of phylogenetic diversity. It is likely that more individuals successfully reached and established closer to the cerrado edge because of higher propagule pressure. Edgeinterior gradients in species richness, density, and dispersal have also been found previously in the first $25 \mathrm{~m}$ from a cerrado edge with a Eucalyptus spp. plantation understorey elsewhere (Neri et al. 2005). The current study indicates that such gradients may also occur over larger distances (up to $185 \mathrm{~m}$ ) and also occur for phylogenetic diversity and distributions of abundant species. Furthermore, the PD-rate increased modestly from the cerrado to the forest edge, while both PD and species number decreased. This indicates that: 1) at cerrado edge, there were more species which were phylogenetically similar, so that each of them added little phylogenetic diversity to these sites; 2) conversely, there were fewer species at the forest edge, but the phylogenetic distances among these species were greater. For example, Cabralea canjerana and Cedrela fissilis (Meliaceae), species that are more common in forest than in cerrado, appeared only close to the forest edge and are from a different family than the most abundant species (Schefflera vinosa, O. pulchella, P. acuminatus, Myrcia lingua, Solanum paniculatum, Myrsine umbellata and M. coriaceae). Myrtaceae and Fabaceae were among the most abundant and species-rich families and were distributed more or less evenly along the transects.

Plants inside the study site were smaller than those at either edge. These differences were more pronounced than could be explained solely by increased light near the edges of the study site (Bowering et al. 2006; Delgado et al. 2007; Pohlman et al. 2007). Time since establishment is a plausible alternative explanation. This explanation is also consistent with the results for height standard deviation and coefficient of variation, indicating that plant height in the interior of the site is more homogeneous and consequently that understorey plants had a shorter time to develop in the interior of the site than at the edges. In addition, allelopathic effects of $\mathrm{Eu}$ calyptus spp. could hinder development of trees, causing the trough pattern observed for height, as these effects would be stronger in the centre of the fragment (del Moral and Muller 1970; May and Ash 1990; Khan et al. 2008). Overall density of all understorey species decreased linearly from the cerrado to the forest edge. This may be because cerrado species are more adapted than forest species to the nutrient-poor soils present at this study site (Haridasan 2000; Ruggiero et al. 2002) and so are more likely to colonise the study site than forest species. This also indicates that allelopathic effects of 
Eucalyptus grandis do not affect the establishment of new individuals in a spatially explicit manner. Thus, even though forest species are capable of being dispersed into the site, the establishment and survival of species dispersed from the cerrado would be greater, explaining the observed gradient. Other factors, such as differences in soil or shading, may also have played a role. However, their importance was probably smaller, as these characteristics appeared to be reasonably homogeneous in the area and the light levels were sufficient for the establishment and growth of the cerrado species.

With regard to dispersal, the proportion of animaland self-dispersed individuals, but not species, varied along the gradient. Animal dispersal was the predominant syndrome, as expected for cerrado vegetation (Batalha and Mantovani 2000; Jardim and Batalha 2009), and the proportion of animal-dispersed plants decreased from the cerrado to the forest edge. A decrease in the number of animal-dispersed plants from edge to interior of a Eucalyptus sp. plantation has also been observed in a smaller-scale study (Neri et al. 2005), whereas a study in native cerrado vegetation showed an opposite pattern, with the number of animal-dispersed individuals being smallest at the edge (Jardim and Batalha 2009). From these results, it seems that the fauna in the cerrado that is capable of dispersing seeds avoids both agricultural land (Jardim and Batalha 2009) and the interior of explantation areas (Neri et al. 2005 and present study). It is known that Eucalyptus plantations may be used as corridor and habitat by top predators such as Puma concolor and Chrysocyon brachiurus (Lyra-Jorge et al. 2010). However, the use of such areas by seed-dispersing fauna in general seems to be reduced, indicating that this is a poor habitat for a large proportion of the fauna, especially birds. This is similar to what has been observed in a study of avifauna in fragments of Atlantic Forest and Eucalyptus sp. plantation, where the number of birds recorded in the plantation was less than half of that recorded in the forest fragments in spite of a welldeveloped undergrowth (Dário et al. 2002). Thus, the use of study area as a dispersal corridor by animals is probably below the desired levels.

\section{Conclusions}

The area studied here was located between two different vegetation types and gradients were observed in both species composition and vegetation structure. The results from this study indicate that the presence of Eucalyptus grandis trees from an abandoned plantation does not preclude colonisation of native species from neighbouring cerrado and forest patches. The understorey composition resulting from the succession process was spatially heterogeneous, with a clear pattern in vegetation structure and composition. Thus, the main driving factor of heterogeneity is the distance to areas of native vegetation. Natural regeneration under Eucalyptus plantations may be a viable form of restoration given adequate management, and any removal of residual Eucalyptus trees should be done gradually to prevent damage to the existing understorey.

\section{Abbreviations}

CV: Coefficient of variation; PD: Phylogenetic diversity; SD: Standard deviation.

\section{Competing interests}

The authors declare that they have no competing interests.

\section{Authors' contributions}

All authors participated in data collection, identification of species, data analysis and writing of the manuscript and read and approved the final manuscript.

\section{Acknowledgements}

We are very grateful: to Jorge Yoshio Tamashiro for identifying many of species; Eduardo Hettwer Giehl, Igor Aurélio, Anne Maguran and Karen Harper, as well as the editor and three anonymous reviewers, for suggestions on a previous version of this manuscript; CNPq (National Counsel of Technological and Scientific Development) for scholarship granted to PD; Fapesp (State of São Paulo Research Foundation) for scholarship granted to NBR; and Capes (Coordination for the Improvement of Higher Education Personnel) for scholarship granted to DMS.

\section{Author details}

${ }^{1}$ Department of Hidrobiology, Federal University of São Carlos, P.O. Box 676, São Carlos 13565-905, SP, Brazil. Department of Environmental Sciences, Federal University of São Carlos, P.O. Box 676, São Carlos 13565-905, SP, Brazil. 'Department of Botany, Federal University of São Carlos, P.O. Box 676, São Carlos 13565-905, SP, Brazil.

Received: 22 March 2013 Accepted: 24 February 2014 Published online: 18 June 2014

\section{References}

Almeida, SP, Proença, CEB, Sano, SM, \& Ribeiro, JF. (1998). Cerrado: espécies vegetais úteis. Planaltina: Embrapa - CPAC.

Angiosperm Phylogeny Group III. (2009). An update of the Angiosperm Phylogeny Group classification for the orders and families of flowering plants: APG III. Botanical Journal of the Linnean Society, 161, 105-121.

Batalha, MA, \& Mantovani, W. (2000). Some phenological patterns of cerrado plant species at the Pé-de-Gigante reserve (Santa Rita do Passa Quatro, SP, Brazil): a comparison between the herbaceous and woody floras. Brazilian Journal of Biology, 59, 1-16.

Borgo, M. (2010). A Floresta Atlântica do litoral norte do Paraná, Brasil: aspectos florísticos, estruturais e estoque de biomassa ao longo do processo sucessional. Universidade Federal do Paraná, Curitiba: PhD thesis.

Bowering, M, Lemay, V, \& Marshall, P. (2006). Effects of forest roads on the growth of adjacent lodgepole pine trees. Canadian Journal of Forest Research, 36, 919-929.

Cadenasso, ML, Pickett, STA, Weathers, KC, \& Jones, CG. (2003). A framework for a theory of ecological boundaries. Bioscience, 53, 750-758.

Campos, EP, Vieira, MF, Silva, AF, Martins, SV, Carmo, FMS, Moura, VM, \& Ribeiro, ASS. (2009). Chuva de sementes em Floresta Estacional Semidecidual em Viçosa, MG, Brasil. Acta Botanica Brasilica, 23, 451-458.

Candiani, G. (2006). Regeneração natural em áreas anteriormente ocupadas por florestas de Eucalytus saligna Smith. MSc dissertation, Instituto de Botânica, Secretaria do Meio Ambiente do Estado de São Paulo: no município de Caieiras (SP): subsídios para recuperação florestal.

Carvalho, GH, Cianciaruso, MV, \& Batalha, MA. (2010). Plantminer: A web tool for checking and gathering plant species taxonomic information. Environmental Modelling \& Software, 25, 815-816.

Catharino, ELM, Bernacci, LC, Franco, GADC, Durigan, G, \& Metzger, JP. (2006). Aspectos da composição e diversidade do componente arbóreo das florestas da Reserva Florestal do Morro Grande, Cotia, SP. Biota Neotropica, 6(2), art2. 
Chase, JM. (2003). Community assembly: when should history matter? Oecologia, 136, 489-498.

Coelho, GC, Rigo, MS, Libardoni, JB, Oliveira, R, \& Benvenuti-Ferreira, G. (2010). Understory structure in two successional stages of a Semi-deciduous Seasonal Forest remnant of southern Brazil. Biota Neotropica, $11(3)$, art4.

Dantas, VL, \& Batalha, MA. (2011). Vegetation structure: fine scale relationships with soil in a cerrado site. Flora, 206, 341-346.

Dário, FR, De Vincenzo, MCV, \& Almeida, AF. (2002). Avifauna em fragmentos de mata atlântica. Ciencia Rural, 32, 989-996.

del Moral, R, \& Mullher, CH. (1970). The allelopathic effects of Eucalyptus camaldulensis. American Midland Naturalist, 83, 254-282.

Delgado, JD, Arroyo, NL, Arévalo, JS, \& Fernández-Palacios, JM. (2007). Edge effects of roads on temperature, light, canopy cover, and canopy height in laurel and pine forests (Tenerife, Canary Islands). Landscape and Urban Planning, 81, 328-340.

Durigan, G, \& Ratter, JA. (2006). Successional changes in cerrado and cerrado/ forest ecotonal vegetation in western São Paulo state, Brazil, 1962-2000. Edinburgh Journal of Botany, 63, 119-130.

Durigan, G, Contiere, WA, Franco, GADC, \& Garrido, MAO. (1998). Indução do processo de regeneração da vegetação de cerrado em área de pastagem, Assis, SP. Acta Botanica Brasilica, 12, 421-429.

Durigan, G, Melo, ACG, Max, JCM, Bôas, OV, \& Contiere, WA. (2003). Manual para recuperação da vegetaçào de cerrado. São Paulo: Instituto Florestal.

Durigan, G, Siqueira, MF, \& Franco, GADC. (2007). Threats to the Cerrado remnants of the state of São Paulo, Brazil. Scientia Agricola, 64, 355-363.

Faith, D. (1992). Conservation evaluation and phylogenetic diversity. Biological Conservation, 61, 1-10

Francisco, MR, \& Galetti, M. (2002). Aves como potenciais dispersoras de sementes de Ocotea pulchella Mart. (Lauraceae) numa área de vegetação de cerrado do sudeste brasileiro. Revista Brasileira de Botânica, 25, 11-17.

Frenedozo, RC. (2004). Plant reproductive phenology and dispersal patterns after natural regeneration in a limestone mining spoil banks. Brazilian Archives of Biology and Technology, 47, 261-271.

Furley, PA, Proctor, J, \& Ratter, JA. (1992). Nature and dynamics of forest-savanna boundaries. London: Chapman and Hall.

Galetti, M, Pizo, MA, \& Morellato, LPC. (2011). Diversity of functional traits of flesh fruits in a species-rich Atlantic rain forest. Biota Neotropica, 11, art18.

Giehl, ELH, Athayde, EA, Budke, JC, Gesing, JPA, Eisinger, SM, \& Canto-Dorow, TS. (2007). Espectro e distribuição vertical das estratégias de dispersão de diásporos do componente arbóreo em uma floresta estacional no sul do Brasil. Acta Botanica Brasilica, 21, 137-145.

Goldenberg, R, \& Shepherd, GJ. (1998). Studies on the reproductive biology of Melastomataceae in "cerrado" vegetation. Plant Systematics and Evolution, $211,13-29$

Gonçalves, CS, \& Batalha, MA. (2011). Towards testing the "honeycomb rippling model" in cerrado. Brazilian Journal of Biology, 71, 401-408.

Grau, HR, Arturi, MF, Brown, AD, \& Acenõlaza, PG. (1997). Floristic and structural patterns along a chronosequence of secondary forest succession in Argentinean Subtropical Montane Forest. Forest Ecology and Management, 95, 161-171.

Gressler, E, Pizo, MA, \& Morellato, LPC. (2006). Polinização e dispersão de sementes em Myrtaceae do Brasil. Revista Brasileira de Botânica, 29, 509-530.

Hammer, Ø, Harper, DAT, Ryan, PD. (2001). PAST: Paleontological Statistics Software Package for Education and Data Analysis. Palaeontologia Electronica 4, 9 pp. Available at http://palaeo-electronica.org/2001_1/past/issue1_01.htm. Accessed 24 Jan 2014

Haridasan, M. (2000). Nutrição mineral de plantas nativas do cerrado. Revista Brasileira de Fisiologia Vegetal, 12, 54-64.

Harper, KA, Macdonald, SE, Burton, PK, Chen, JQ, Brosofske, KD, Saunders, SC, Euskirchen, ES, Roberts, D, Jaiteh, MS, \& Esseen, PA. (2005). Edge influence on forest structure and composition in fragmented landscapes. Conservation Biology, 19, 768-782.

Hoffmann, WA, \& Solbrig, OT. (2003). The role of topkill in the differential response of savanna woody species to fire. Forest Ecology and Management 180, 273-286

Ishara, KL, \& Maimoni-Rodella, RCS. (2011). Pollination and dispersal systems in a cerrado remnant (Brazilian Savanna) in southeastern Brazil. Brazilian Archives of Biology and Technology, 54, 629-642.

Jardim, AVF, \& Batalha, MA. (2009). Dispersal syndromes related to edge distance in cerrado sensu stricto fragments of Central-Western Brazil. Brazilian Archives of Biology and Technology, 52, 1167-1177.
Jepson, W. (2005). A disappearing biome? Reconsidering land-cover change in the Brazilian savanna. The Geographical Journal, 171, 99-111.

Jost, L, Chao, A, \& Chazdon, RL. (2011). Compositional similarity and B diversity. In AE Magurran \& BJ McGill (Eds.), Biological diversity: frontiers in measurement and assessment (pp. 66-84). Oxford: Oxford University Press, Oxford.

Khan, MA, Hussain, I, \& Khan, EA. (2008). Suppressing effects of Eucalyptus camaldulensis $\mathrm{L}$. on germination and seedling growth of six weeds. Pakistan Journal of Weed Science Research, 14, 201-207.

Lebrija-Trejos, E, Perez-Garcia, EA, Meave, JA, Bongers, F, \& Poorter, L. (2010). Functional traits and environmental filtering drive community assembly in a species-rich tropical system. Ecology, 91, 386-398.

Liebsch, D, Mikich, SB, Possette, RFS, \& Ribas, OS. (2009). Levantamento florístico e síndromes de dispersão em remanescentes de Floresta Ombrófila Mista na região centro-sul do estado do Paraná. Hoehnea, 36, 233-248.

Lobão, AQ, \& Mello-Silva, R. (2007). Guatteria (Annonaceae) do estado do Rio de Janeiro, Brasil. Rodriguésia, 58, 859-884.

Lyra-Jorge, MC, Ciocheti, G, \& Pivello, VR. (2008). Carnivore mammals in a fragmented landscape in northeast of São Paulo State, Brazil. Biodiversity and Conservation, 17, 1573-1580

Lyra-Jorge, MC, Ribeiro, MC, Ciocheti, G, Tambosi, LR, \& Pivello, VR. (2010). Influence of multi-scale landscape structure on the ocurrence of carnivorous mammals in a human-modified savanna, Brazil. European Journal of Wildlife Research, 56, 359-368.

Machado, RB, \& Lamas, IR. (1996). Avifauna associada a um reflorestamento de eucalipto no município de Antônio Dias, Minas gerais. Ararajuba, 4, 15-22.

Magurran, AE. (1988). Biological diversity and its measurement. Princeton: Princeton University Press.

Maurer, BA, \& Mcgill, BJ. (2011). Measurement of species diversity. In AE Magurran \& BJ McGill (Eds.), Biological diversity: frontiers in measurement and assessment (pp. 55-65). Oxford: Oxford University Press.

May, FE, \& Ash, JE. (1990). An assessment of the allelopathic potential of Eucalyptus. Australian Journal of Botany, 38, 245-254.

Miranda, HS, Bustamante, MMC, \& Miranda, AC. (2002). The fire factor. In PS Oliveira \& RJ Marquis (Eds.), The Cerrados of Brazil: ecology and natural history of a neotropical savanna (pp. 51-68). New York: Columbia University Press.

Missouri Botanical Garden. (2012). Tropicos database. http://www.tropicos.org/. Acessed 11 June 2012.

Moreira, AG. (2000). Effects of fire protection on savanna structure in Central Brazil. Journal of Biogeography, 27, 1021-1029.

Moura, FBP, Duarte, JMM, \& Lyra-Lemos, RP. (2011). Floristic composition and dispersal syndromes at an urban remnant from the Atlantic forest in Brazilian northeast. Acta Scientiarum Biological Sciences, 33, 471-478.

Neri, AV, Campos, EP, Duarte, TG, Meira Neto, JAA, Silva, AF, \& Valente, GE. (2005). Regeneração de espécies nativas lenhosas sob plantio de Eucalyptus em área de cerrado na Floresta Nacional de Paraopeba, MG, Brasil. Acta Botanica Brasilica, 19, 369-376.

Paise, G, \& Viera, EM. (2005). Produção de frutos e distribuição espacial de angiospermas com frutos zoocóricos em uma Floresta Ombrófila Mista no Rio Grande do Sul, Brasil. Revista Brasileira de Botânica, 28, 615-625.

Pascotto, MC. (2007). Rapanea ferruginea (Ruiz and Pav.) Mez. (Myrsinaceae) como uma importante fonte alimentar para as aves em uma mata galeria no interior do estado de São Paulo. Revista Brasileira de Zoologia, 24, 735-741.

Pohlman, CL, Turton, SM, \& Goosem, M. (2007). Edge effects of linear canopy openings on tropical rain forest understorey microclimate. Biotropica, 39, 62-71.

Polisel, RT, \& Franco, GADC. (2010). Comparação florística e estrutural entre dois trechos de Floresta Ombrófila Densa em diferentes estádios sucessionais, Juquitiba, SP, Brasil. Hoehnea, 37, 691-718.

Pouliot, R, Rochefort, L, \& Karofeld, E. (2012). Initiation of microtopography in re-vegetated cutover peatlands: evolution of plant species composition. Applied Vegetation Science, 15, 369-382.

R Development Core Team. (2012). R: A language and environment for statistical computing. R Foundation for Statistical Computing, Vienna, Austria. http://www.r-project.org/. Accessed 11 June 2012.

Ressel, K, Guilherme, FAG, Schiavini, I, \& Oliveira, PE. (2004). Ecologia morfofuncional de plântulas de espécies arbóreas da Estação Ecológica do Panga, Uberlândia, Minas Gerais. Revista Brasileira de Botânica, $27,311-323$

Reys, P, Galetti, M, Morellato, LPC, \& Sabino, J. (2005). Fenologia reprodutiva e disponibilidade de frutos de espécies arbóreas em mata ciliar no rio Formoso, Mato Grosso do Sul. Biota Neotropica, 5, ShortComm2. 
Ruggiero, PGC, Batalha, MA, Pivello, VR, \& Meirelles, ST. (2002). Soil-vegetation relationships in cerrado (Brazilian savanna) and semideciduous forest, southeasthern Brazil. Plant Ecology, 160, 1-16.

Santos, JE, Paese, A, \& Pires, JSR. (1999). Unidades da paisagem (biótopos) do câmpus da UFSCar. São Carlos: EdUFSCar.

Saporetti, AW, Jr, Meira Neto, JAA, \& Almado, R. (2003). Phytosociology of a cerrado understorey in a stand of Eucalyptus grandis W. Hill ex Maiden in Bom Despacho-MG. Revista Árvore, 27, 905-910.

Silva, IA, Cianciaruso, MV, \& Batalha, MA. (2009). Dispersal modes and fruiting periods in hyperseasonal and seasonal savannas, central Brazil. Revista Brasileira de Botânica, 32, 155-163.

Spina, AP, Ferreira, WM, \& Leitao Filho, HF. (2001). Floração, frutificação e síndromes de dispersão de uma comunidade de floresta de brejo na região de Campinas (SP). Acta botanica Brasilica, 15, 349-368.

Stefanello, D, Fernandes-Bulhão, C, \& Martins, V. (2009). Síndromes de dispersão de sementes em três trechos de vegetação ciliar (nascente, meio e foz) ao longo do rio Pindaíba, MT. Revista Árvore, 33, 1051-1061.

Taguchi, Y-H, \& Oono, Y. (2005). Nonmetric multidimensional scaling as a datamining tool: new algorithm and new targets. In M Toda, T Komatsuzaki, T Konishi, RS Berry, \& SA Rice (Eds.), Geometric structures of phase space in multidimensional chaos: applications to phemical reaction dynamics in complex systems (Vol. 130). Hoboken: John Wiley \& Sons.

Takahasi, A, \& Fina, BG. (2004). Síndromes de dispersão de sementes de uma área do Morro de Paxixi, Aquidauana, MS, Brasil (In IV Simpósio sobre recursos naturais e sócio-econômicos do Pantanal [IV Symposium on the natural and economical resources of the Pantanal]). MS, Brazil: Corumbá.

Tannus, JLS, Assis, MA, \& Morellato, LPC. (2006). Fenologia reprodutiva em campo sujo e campo úmido numa área de Cerrado no sudeste do Brasil, Itirapina - SP. Biota Neotropica, 6, art8.

The Plant List. (2010). Version 1. http://www.theplantlist.org/. Acessed 11 June 2012.

Török, P, Kelemen, A, Valkó, O, Deák, B, Lukács, B, \& Tóthmérész, B. (2011). Lucerne-dominated fields recover native grass diversity without intensive management actions. Journal of Applied Ecology, 48, 257-264.

Webb, CO, \& Donoghue, MJ. (2005). Phylomatic: tree assembly for applied phylogenetics. Molecular Ecology Notes, 5, 181-183.

Webb, CO, Ackerly, D, \& McPeek, M. (2002). Phylogenies and community ecology. Annual Review of Ecology, Evolution and Systematics, 33, 475-505.

Webb, CO, Ackerly, DD, \& Kembel, SW. (2008). Phylocom: software for the analysis of phylogenetic community structure and trait evolution. Bioinformatics, 24, 2098-2100

Weisbauer, MB, Giehl, ELH, \& Jarenkow, JA. (2008). Padrões morfológicos de diásporos de árvores e arvoretas zoocóricas no Parque Estadual de Itapuã, RS, Brasil. Acta Botanica Brasilica, 22, 425-435.

Weiser, VL, \& Godoy, SAP. (2001). Florística em um hectare de cerrado stricto sensu na ARIE - Cerrado Pé-de-Gigante, Santa Rita do Passa Quatro, SP. Acta Botanica Brasilica, 15, 201-212.

Wikström, N, Savolainen, V, \& Chase, MW. (2001). Evolution of the angiosperms: calibrating the family tree. Proceedings of the Royal Society B: Biological Sciences, 268, 2211-2220.

Wolters, M, Garbutt, RA, \& Bakker, JP. (2005). Plant colonisation after managed realignment: the relative importance of diaspore dispersal. Journal of Applied Ecology, 42, 770-777.

Wulf, M, \& Heinken, T. (2008). Colonization of recent coniferous versus deciduous forest stands by vascular plants at the local scale. Applied Vegetation Science, $11,307-316$.

Yamamoto, LF, Kinoshita, LS, \& Martins, FR. (2007). Síndromes de polinização e dispersão em fragmentos da Floresta Estacional Semidecídua Montana, SP, Brasil. Acta Botanica Brasilica, 21, 553-573.

Ye, WH, Mu, HP, Cao, HL, \& Ge, XJ. (2004). Genetic structure of the invasive Chromolaena odorata in China. Weed Research, 44, 129-135.

Zipparro, VB, Guilherme, FAG, Almeida-Scabbia, RJ, \& Morellato, LPC. (2005). Levantamento florístico de Floresta Atlântica no sul do estado de São Paulo, Parque Estadual Intervales, base Saibadela. Biota Neotropica, 5(1), Inv1.

doi:10.1186/s40490-014-0010-y

Cite this article as: Dodonov et al: Understorey vegetation gradient in a Eucalyptus grandis plantation between a savanna and a semideciduous forest. New Zealand Journal of Forestry Science 2014 44:10.

\section{Submit your manuscript to a SpringerOpen ${ }^{\odot}$ journal and benefit from:}

- Convenient online submission

- Rigorous peer review

- Immediate publication on acceptance

- Open access: articles freely available online

- High visibility within the field

- Retaining the copyright to your article

Submit your next manuscript at $\gg$ springeropen.com 